\title{
Formalisasi sektor informal: Proses, faktor pengaruh, dan dampak pada pelaku usaha sektor informal di Kota Palembang
}

\section{Formalisation of the informal sector: Process, influential factors, and effects on informal workers in Palembang City}

\author{
Armansyah $^{1,2}$, Sukamdi $^{1 *}$ \\ 'Program Studi S3 Ilmu Kependudukan Sekolah Pascasarjana Universitas Gadjah Mada \\ ${ }^{2}$ Program Studi Pendidikan Geografi Universitas PGRI Palembang
}

*Korespondensi penulis: sukamdi@ugm.ac.id

\begin{abstract}
This study aims to examine the process of formalizing informal sector through an analysis of characteristics of informal and formal sectors, factors affecting the formalization process, and its impact on informal sector actors in Palembang City. This study combines quantitative and qualitative methods with sequential explanatory designs. Quantitative data collection are conducted through survey, while qualitative data are gathered through in-depth interviews. Informants for this study are informal business actor who stayed in Palembang and have run their business for at least 1 year. Quantitative data analysis using Chi-square test and descriptive frequencies, while qualitative data analysis uses three stages, namely, reduction, display, and conclusion. The formalization process can be classified into three stages, namely the informal, transition, and formal stages. Most informal business actors in Palembang are still at the informal stage. The process of formalizing the informal sector in Palembang does not occur systematically, but rather with random or up and down patterns. The results also shows that the process of formalization of the informal sector is largely based on the initiative of business actors. In addition, informal businesses that have undergone a formalization process tend to have better income and business security.
\end{abstract}

Keywords: formalization, informal sector, labour, economy

\begin{abstract}
ABSTRAK
Penelitian ini bertujuan untuk mengkaji proses formalisasi sektor informal melalui analisis karakteristik sektor informal dan formal, faktor yang memengaruhi terjadinya proses formalisasi, dan dampak terhadap pelaku usaha sektor informal di Kota Palembang. Kajian ini menggabungkan metode kuantitatif dan kualitatif dengan desain eksplanatori sekuensial. Pengumpulan data menggunakan metode survei dan wawancara mendalam terhadap pelaku usaha sektor informal yang berdomisili di Kota Palembang dan telah menjalankan usaha minimal satu tahun. Analisis data kuantitatif menggunakan uji Chi-square dan deskriptif frekuensi, sedangkan analisis data kualitatif menggunakan tiga tahapan, yaitu reduction, display, dan conclusion. Proses formalisasi dapat diklasifikasikan menjadi tiga tahapan, yaitu tahap informal, transisi, dan formal dan mayoritas kegiatan usaha yang dikaji masih berada pada tahap informal. Proses formalisasi sektor informal di Kota Palembang tidak terjadi secara sistematis, melainkan dengan pola 'acak' atau 'naik-turun'. Hasil penelitian juga menunjukkan bahwa sebagian besar proses formalisasi sektor informal terjadi atas inisiatif pelaku usaha. Pelaku usaha sektor informal yang telah mengalami proses formalisasi cenderung memiliki pendapatan yang lebih baik dan keamanan usaha.
\end{abstract}

Kata kunci: formalisasi, sektor informal, ketenagakerjaan, ekonomi

\section{PENDAHULUAN}

Sektor informal merupakan strategi bertahan hidup populer yang telah dilakukan para pencari kerja sejak revolusi industri 1.0 hingga 4.0. ILO (2016) mendefinisikan sektor informal sebagai jenis pekerjaan yang berada di luar regulasi sektor formal. Sektor informal juga mencakup usaha kecil dan mikro yang tidak diregulasi dan tidak terdaftar (Nazara, 2010). Sektor informal dapat diidentifikasi berdasarkan jenis pekerjaan dan status usaha. Aktivitas ekonomi berupa usaha sendiri, usaha sendiri dengan bantuan keluarga 
atau anggota keluarga dengan tidak dibayar, pekerja musiman di bidang pertanian, pekerja musiman di bidang nonpertanian, dan pekerja tidak dibayar dapat digolongkan sebagai aktivitas sektor informal (BPS, 2017). Pelaku usaha sektor informal dalam kajian ini meliputi mereka yang berusaha sendiri atau mereka yang berperan sebagai pemilik sekaligus pekerja sektor informal.

Sektor informal memiliki beragam karakteristik, antara lain tidak membayar pajak, persisten (Gibson \& Flaherty, 2016), fleksibel (Soebyakto \& Armansyah, 2016; Armansyah \& Aryaningrum, 2017), adaptif (Pitoyo, 1999), pendidikan dan keterampilan rendah (Ramdan, 2012; Armansyah \& Taufik, 2018), serta miskin (Chen \& Vanek, 2013). Sektor informal menjadi strategi bertahan hidup yang populer bagi pencari kerja yang belum bisa beradaptasi dengan globalisasi, gagal memasuki lapangan kerja formal, kalah bersaing atau terkena PHK (Canclini, 2018). Namun, di balik eksistensi dan perkembangannya, perspektif negatif pada sektor informal sampai saat ini tetap ada. Hal ini terlihat dari masih banyaknya perlakuan negatif terhadap pelaku usaha sektor informal, seperti penggusuran, pengusiran, punggutan liar, dan bahkan pelecehan (Wauran, 2012).

Bagi pihak tertentu, sektor informal kerap dianggap sebagai penganggu (Chirisa, 2014), tetapi sektor informal juga dapat menjadi media bertahan hidup bagi masyarakat menengah ke bawah (Armansyah dkk., 2019). Kemampuan sektor informal dalam memberikan peluang pendapatan merupakan salah satu faktor penarik bagi pencari kerja daripada menganggur (Wulantari \& Armansyah, 2018), bahkan mampu memberikan nilai tambah bagi penghasilan rumah tangga (Taufik dkk., 2019). Fleksibilitas sektor informal yang mampu menampung semua karakteristik pencari kerja juga menjadi faktor penarik lainnya (Soebyakto \& Armansyah, 2016). Beberapa faktor tersebut dapat menjadi alasan tingginya pekerja sektor informal di negara berkembang, khususnya di Indonesia.

Pada bulan Agustus 2018, jumlah pekerja sektor informal Indonesia tercatat sebesar $56,84 \%$. Persentase terbesar pekerja sektor informal adalah mereka dengan status berusaha sendiri. Di Provinsi Sumatera Selatan, proporsi pekerja sektor informal $(62,4 \%)$ juga lebih tinggi dari pekerja sektor formal (BPS, 2018). Kajian sektor informal pada studi ini difokuskan di Kota Palembang, ibu kota provinsi ini. Kota Palembang merupakan wilayah dengan konsentrasi penduduk $(19,63 \%)$ dan kegiatan usaha $(23,65 \%)$ terbesar dibanding kota/kabupaten lainnya di Provinsi Sumatera Selatan (BPS, 2018).

Untuk merespons keberadaan pekerja sektor informal di Palembang, pemerintah kota dan provinsi telah melakukan berbagai upaya intervensi, antara lain penyediaan Asuransi Kesehatan Sosial (Askesos) bagi pekerja sektor informal ("Pekerja sektor informal", 2012), peningkatan partisipasi pekerja sektor informal dalam BPJS Ketenagakerjaan ("BPJS Ketenagakerjaan", 2017), penyediaan rumah murah ("Walikota Palembang”, 2012), relokasi, pembinaan, dan bantuan modal usaha. Intervensi tersebut berdampak tidak langsung pada dinamika sektor informal. Dinamika yang dimaksud adalah transisi karakteristik pelaku usaha dari informal ke formal. Misalnya, perubahan dari tidak ada izin usaha menjadi ada izin usaha, serta dari tidak membayar pajak menjadi berkenan membayar pajak.

Proses perubahan tersebut menjadi objek kajian penelitian ini. Identikasi perubahan tersebut menggunakan analisis karakteristik sektor informal dan formal. Proses perubahan atau transisi karakteristik dari informal ke formal dalam penelitian ini disebut dengan istilah 'formalisasi'. Formalisasi secara umum bermakna keseragaman atau kesesuaian (Mahmuddin, 2015). Jika dihubungkan dengan sektor informal, formalisasi dapat bermakna usaha yang dilakukan untuk menjadikan praktik informal menjadi formal atau sesuai aturan yang berlaku (Rahmatunnair, 2012; Smart \& Smart, 2017), dengan diikuti oleh peningkatan hak-hak pekerja sesuai dengan aturan yang berlaku (Olmedo \& Murray, 2002). Formalisasi sektor informal sendiri merupakan salah satu upaya menciptakan pekerjaan layak untuk semua yang ditargetkan tercapai pada 2030 sesuai dengan yang diamanatkan pada Tujuan Pembangunan Berkelanjutan (Sustainable Development Goals - SDGs) (ILO, 2016). Tu- 
lisan ini menguraikan proses formalisasi sektor informal yang terjadi di Kota Palembang, yang mencakup identikasi proses formalisasi, faktor penentu keputusan melakukan formalisasi, dan dampak formalisasi bagi pelaku usaha sektor informal di Kota Palembang.

\section{METODE PENELITIAN}

Penelitian ini menggunakan metode campuran (gabungan metode kuantitatif dan metode kualitatif) dengan desain eksplanatoris sekuensial (Sugiyono, 2016). Dalam desain tersebut, pengumpulan dan analisis data dilakukan menggunakan dua tahap dan sistematis, yaitu metode kuantitatif pada tahap pertama dan metode kualitatif pada tahap kedua (Gambar 1). Metode ini digunakan untuk menghasilkan informasi yang komprehensif atas permasalahan penelitian. Penggunaan metode kualitatif sebagai tindak lanjut dari temuan kuantitatif dan alat mengkaji informasi secara lebih mendalam. Pada tahap pertama, peneliti mengumpulkan data menggunakan metode survei melalui penyebaran kuesioner. Survei dilakukan pada bulan April - Mei 2019 dengan melibatkan enam orang enumerator. Data yang terkumpul dianalisis menggunakan deskriptif frekuensi dan uji Chi-square. Selanjutnya, pengumpulan data kualitatif menggunakan teknik wawancara mendalam pada informan. Analisis data kualitatif menggunakan tiga tahapan, yaitu reduction, display, dan conclusion (Creswell, 2016). Interpretasi hasil dan pembahasan menggunakan uraian deskriptif, tabel, pie chart, dan dialog teoritis menggunakan kajian terdahulu yang relevan.

Populasi penelitian adalah pelaku usaha sektor informal di Kota Palembang sejumlah 1.498 orang. Penentuan sampel menggunakan teknik Krejcie dan Morgan. Teknik sampel Krejcie dan Morgan merupakan teknik penentuan sampel berdasarkan jumlah populasi dengan menggunakan acuan tabel bantu yang disebut Tabel sampel Krecjie dan Morgan, dengan rumus dasar:

$$
\mathrm{S}=\left\{\lambda^{2} \text {. N. P. Q }\right\} /\left\{\mathrm{d}^{2}(\mathrm{~N}-1)+\lambda^{2} \text {. P. Q }\right\}
$$

Keterangan:

S : Jumlah sampel

$\mathrm{N}$ : Populasi penelitian

$\lambda^{2}$ : Lamda (faktor pengali) dengan $\mathrm{dk}=1$, taraf kesalahan alternatif $1 \%, 5 \%$, dan $10 \%$

Q : 0,5 (konstanta)

$\mathrm{d}^{2}: 0,05$ (konstanta)

$\mathrm{P}$ : Populasi menyebar normal

Berdasarkan rumus di atas, sampel penelitian ini ditentukan berjumlah 302 orang. Selanjutnya, penentuan informan wawancara menggunakan purposive sampling. Informan wawancara sebanyak 24 orang yang merupakan pelaku usaha sektor informal yang berdomisili di Kota Palembang dan telah menjalankan usaha informal minimal satu tahun.

Untuk mengkaji dan mengidentifikasi proses formalisasi sektor informal di Kota Palembang, karakteristik sektor informal dikelompokkan menjadi lima dimensi, yaitu hukum, sosial, ekonomi, manajemen, dan ketenagakerjaan (Tabel 1).

Untuk mengidentifikasi proses formalisasi sektor informal, digunakan checklist berdasarkan variabel yang dimiliki oleh pelaku usaha sektor informal di Kota Palembang. Kategori yang digunakan menggunakan pendekatan binary (Brata, 2010), misalnya untuk dimensi hukum,

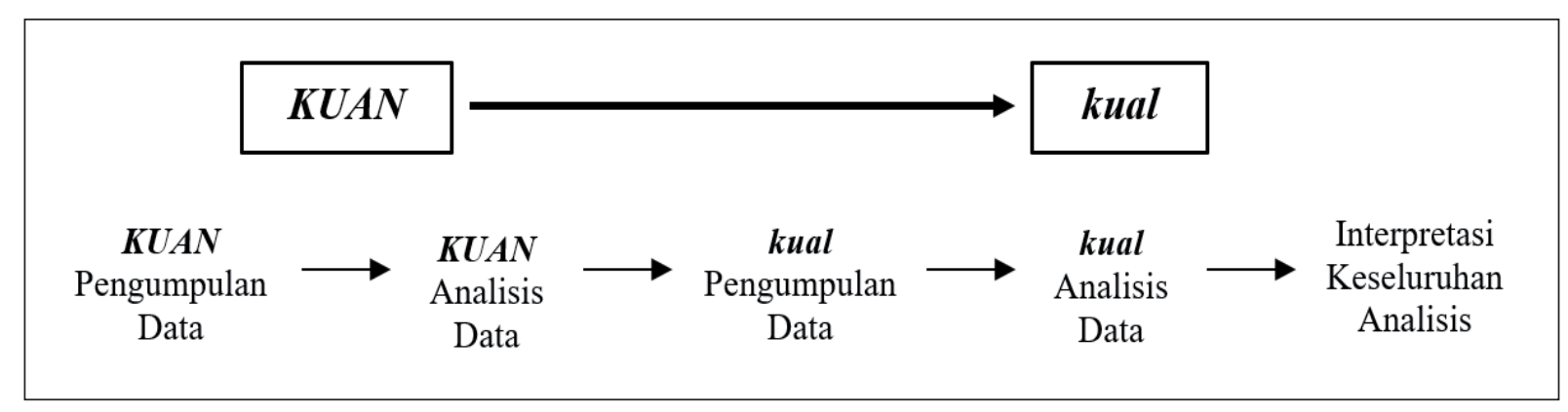

Sumber: Creswell (2016)

Gambar 1. Desain Explanatoris Sekuensial 
Tabel 1. Variabel dan dimensi proses formalisasi sektor informal

\begin{tabular}{cl}
\hline No. Dimensi & \multicolumn{1}{c}{ Variabel } \\
\hline 1. Hukum & 1) Izin usaha; 2) sertifikat; 3) stan- \\
& dar kerja; 4) retribusi; 5) legalitas \\
& lokasi usaha; 6) keamanan; \\
\hline 2. Sosial & 1) Tingkat pendidikan; 2) keteram- \\
& pilan; 3) sumber keterampilan; 4) \\
& jaminan sosial; 5) akses perbankan, \\
\hline 3. Ekonomi & 1) Jumlah modal; 2) sumber \\
& modal; 3) pinjaman modal; 4) \\
& sumber bahan baku; 5) pendapatan; \\
& 6) tabungan; 7) investasi; 8) bentuk \\
& tempat usaha; 9) status tempat \\
& usaha \\
\hline 4. Mana- & 1) Perencanaan; 2) rembuk kerja; \\
jemen & 3) pembukuan; 4) stok barang; \\
& 5) kualitas barang; 6) kerjasama \\
& dengan sektor lain; 7) penggunaan \\
& teknologi; 8) media pemasaran; 9) \\
& target pemasaran; 10) evaluasi
\end{tabular}

5. Ketenaga-

kerjaan

1) Jumlah pekerja; 2) sistem

perekrutan; 3) status hubungan

kerja; 4) hubungan dengan pekerja;

5) sistem pembayaran upah pekerja

pada variabel izin usaha kategori yang digunakan adalah 'tidak ada' dan 'ada'. 'Tidak ada' disimbolkan dengan angka ' 0 ' dan 'ada' disimbolkan dengan angka ' 1 '. Hasil checklist ini menjadi basis klasifikasi pada tiap dimensi untuk mengidentifikasi proses formalisasi sektor informal secara general dan parsial.

\section{HASIL DAN PEMBAHASAN}

\section{Proses Formalisasi Sektor Informal}

Penelitian ini menemukan adanya proses formalisasi sektor informal di Kota Palembang. Hal tersebut ditunjukkan dengan adanya transisi karakteristik pelaku usaha dari informal ke formal pada tiap dimensi proses formalisasi. Secara umum, proses formalisasi sektor informal dibedakan menjadi dua, yaitu formalisasi sektor informal
Tabel 2. Klasifikasi tahapan formalisasi secara parsial dan general

\begin{tabular}{|c|c|c|c|}
\hline Dimensi & Klasifikasi & Label & Nilai \\
\hline \multirow[t]{3}{*}{ Hukum } & Kelas 1 & Informal & 0 \\
\hline & Kelas 2 & Transisi & $1-3$ \\
\hline & Kelas 3 & Formal & $\geq 4$ \\
\hline \multirow[t]{3}{*}{ Sosial } & Kelas 1 & Infomal & 0 \\
\hline & Kelas 2 & Transisi & $1-3$ \\
\hline & Kelas 3 & Formal & $\geq 4$ \\
\hline \multirow[t]{3}{*}{ Ekonomi } & Kelas 1 & Informal & 0 \\
\hline & Kelas 2 & Transisi & $1-4$ \\
\hline & Kelas 3 & Formal & $\geq 5$ \\
\hline \multirow[t]{3}{*}{ Manajemen } & Kelas 1 & Informal & 0 \\
\hline & Kelas 2 & Transisi & $1-5$ \\
\hline & Kelas 3 & Formal & $\geq 6$ \\
\hline \multirow{4}{*}{$\begin{array}{l}\text { Ketenaga- } \\
\text { kerjaan }\end{array}$} & Kelas 1 & Informal & 0 \\
\hline & Kelas 2 & Transisi & $1-3$ \\
\hline & Kelas 3 & Formal & $\geq 4$ \\
\hline & Kelas 1 & Informal & $\leq 10$ \\
\hline \multirow{2}{*}{$\begin{array}{l}\text { Tahapan } \\
\text { Formaisasi }\end{array}$} & Kelas 2 & Transisi & $11-20$ \\
\hline & Kelas 3 & Formal & $\geq 21$ \\
\hline
\end{tabular}

parsial (formalisasi sektor informal pada tiap dimensi), dan formalisasi sektor informal general (gabungan dimensi). Berdasarkan prosesnya, tahapan formalisasi dibedakan menjadi tiga tahapan, yaitu tahap informal, transisi, dan formal. Setiap dimensi diklasifikasikan menjadi tiga kelas, yaitu kelas 1 (informal), kelas 2 (transisi), dan kelas 3 (formal). Klasifikasi tersebut dibuat berdasarkan skor yang diperoleh dari variabel pada tiap dimensi (Tabel 2).

Gambar 2 menyajikan klasifikasi proses formalisasi sektor informal berdasarkan lima dimensi yang dikaji dalam studi ini. Warna merah merupakan simbol kelas 1 (tahap informal), warna kuning merupakan simbol kelas 2 (tahap transisi), dan warna hijau simbol kelas 3 (tahap formal). Selanjutnya, warna coklat pada keliling kelas 1 , 2 dan 3, merupakan simbol dari lima dimensi, yaitu D1 (hukum), D2 (sosial), D3 (ekonomi), D4 (manajemen), D5 (ketenagakerjaan). 


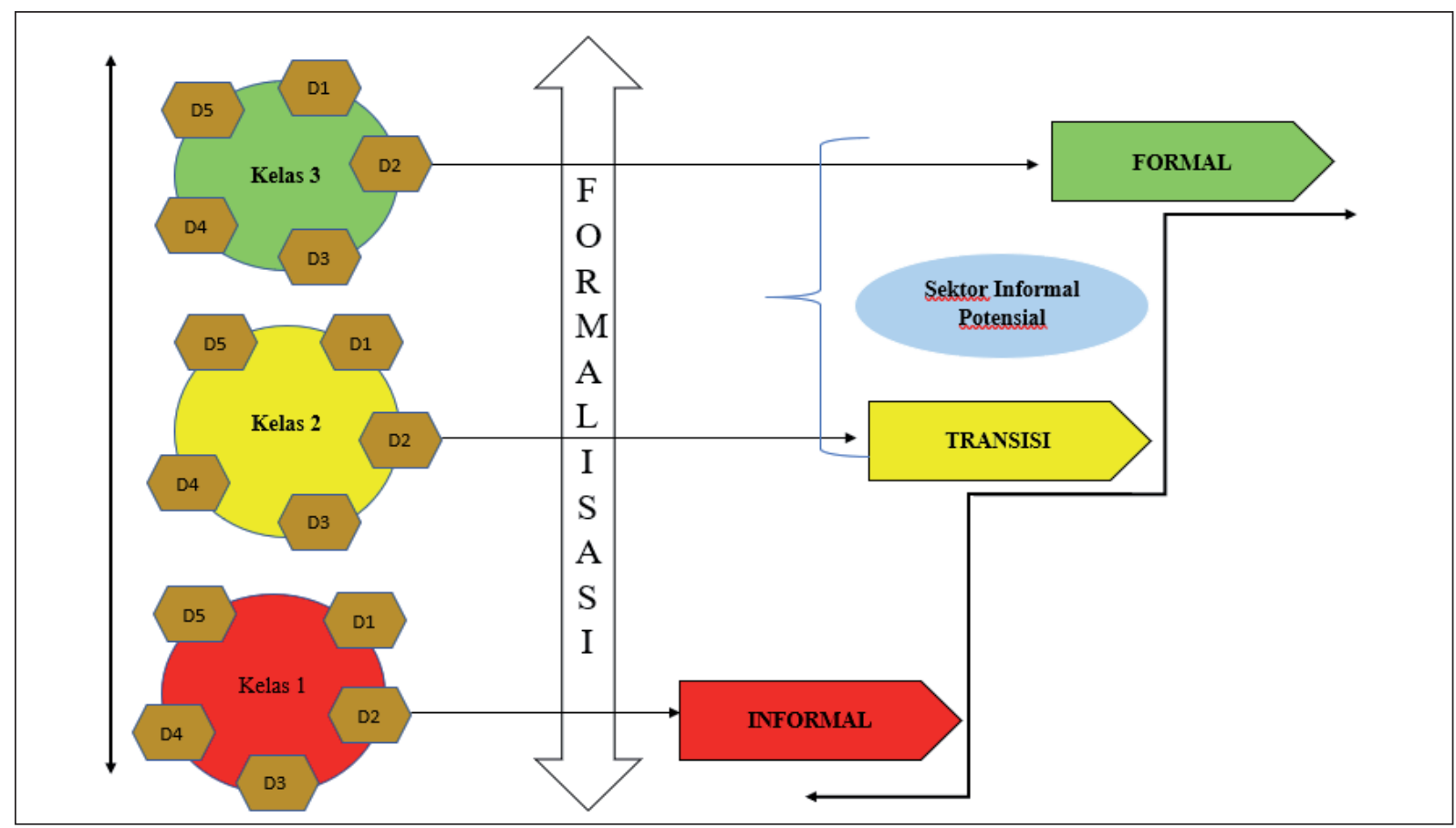

Gambar 2. Klasifikasi proses formalisasi sektor informal di Kota Palembang

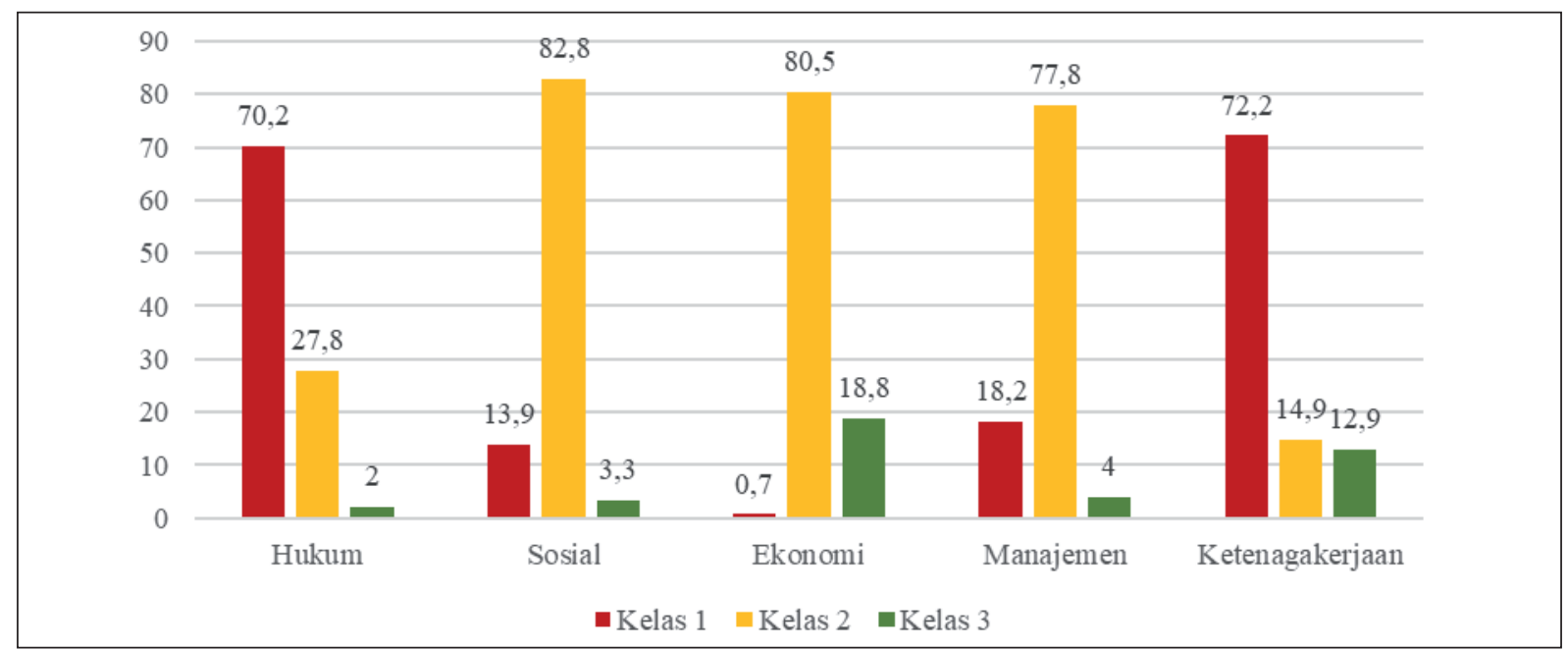

Gambar 3. Persentase klasifikasi tahapan formalisasi pada tiap dimensi

Berdasarkan klasifikasi tersebut, pada dimensi hukum, sekitar 70,2\% pelaku usaha sektor informal berada pada kelas 1 (informal), 27,8\% pada kelas 2 (transisi), dan $2 \%$ pada kelas 3 (formal). Pola serupa juga ditemukan pada dimensi ketenagakerjaan. Persentase terbesar pelaku usaha sektor informal berada pada kelas 1 (informal), diikuti kelas $2(14,9 \%)$ dan kelas $3(12,9 \%)$. Selanjutnya, distribusi responden pada dimensi sosial, ekonomi, dan manajemen menunjukkan bahwa jumlah pelaku usaha sektor informal pada kelas 2 lebih dominan dibandingkan kelas 1 dan kelas 3 (Gambar 3).
Kajian ini juga menemukan bahwa sebagian besar pelaku usaha sektor informal di Palembang berada pada tahap informal (78\%), diikuti transisi (20\%) dan formal (2\%) (Gambar 4). Meskipun jumlah kelas 3 (tahap formal) pada tiap dimensi maupun secara umum memiliki persentase terendah, situasi ini dapat menunjukkan bukti empiris terjadinya proses formalisasi pada sebagian kecil pelaku usaha sektor informal di Kota Palembang.

Dengan demikian, sektor informal yang ada di Kota Palembang tidak dapat dikatakan sepenuhnya informal. Oleh karena itu, perlu adanya gradasi dalam penamaan kegiatan ekonomi 


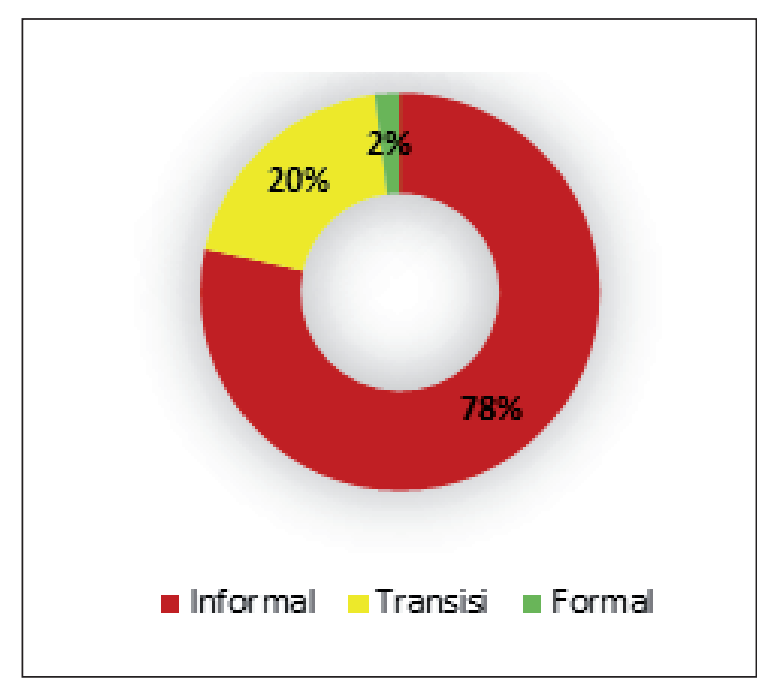

Gambar 4. Persentase pelaku usaha sektor informal berdasarkan tahapan formalisasi

yang berhubungan dengan kegiatan usaha sektor informal. Klasifikasi kegiatan usaha dapat diperbaharui menjadi sektor informal, transisi dan formal. Kegiatan usaha yang tergolong dalam kelompok transisi juga dapat dibagi lagi menjadi kelas transisi awal, tengah dan akhir. Kelompok transisi dan formal juga dapat disebut sebagai 'sektor informal potensial', yaitu sektor informal yang sebagian karakteristiknya telah bertransisi seperti sektor formal. Pengelompokan ini dapat menjadi salah satu alat memetakan usaha sektor informal. Hasilnya dapat ditindaklanjuti dengan pembentukan kelompok dan program pemberdayaan sektor informal potensial di masyarakat. Hal ini sejalan dengan agenda ILO (2016) dan salah satu Tujuan Pembangunan Berkelanjutan (SDGs) yang menargetkan terwujudnya pekerjaan layak untuk semua pada tahun 2030, yang salah satunya dapat ditempuh melalui formalisasi sektor informal.

Gambar 5 menunjukkan bahwa karakteristik yang paling banyak mengalami proses formalisasi adalah tingkat pendapatan. Sebanyak $76,8 \%$ pelaku usaha sektor informal memiliki pendapatan lebih besar dari tiga juta rupiah per bulan atau lebih dari UMK/UMP kabupaten/kota/provinsi. Meskipun ILO (2019) mengemukakan bahwa pelaku usaha informal identik dengan pendapatan rendah dan berada di bawah upah minimum, sektor informal di Kota Palembang menyediakanpeluang pendapatan yang cukup baik untuk pekerjanya. Berdasarkan perspektif fenomenologi dengan subjek pelaku usaha, proses peningkatan pendapatan pada pelaku usaha informal ini dapat digolongkan sebagai proses formalisasi (Sarjono, 2004).

Proses formalisasi berikutnya terjadi pada karakteristik target pemasaran. Sekitar 70,2\% pelaku usaha sektor informal memiliki pengetahuan tentang target pemasaran. Temuan ini relevan dengan Prasetyo dan Harjanti (2013) yang menyatakan bahwa peningkatan usaha akan diikuti oleh peningkatan kemampuan target pemasaran. Ketika pelaku usaha sektor informal mengalami proses formalisasi, situasi ini disertai pula dengan peningkatan kemampuan menentukan target pemasaran (kepada siapa barang/jasa dipasarkan). Selanjutnya, pelaku usaha sektor informal identik dengan pendapatan rendah dan tidak memiliki kemampuan menabung. Kemampuan menabung yang rendah ini menyebabkan pelaku usaha informal sangat rentan terhadap guncangan ekonomi (ILO, 2020). Meskipun begitu, $64,2 \%$ pelaku usaha sektor informal pada studi ini memiliki kemampuan menabung secara rutin setiap bulannya.

Meskipun sektor informal selama ini dipercaya memperoleh sumber bahan baku dari sumber daya lokal, bahkan sumber bahan baku diproduksi sendiri atau diperoleh dari keluarga/ teman/tetangga, kajian ini menemukan $62,6 \%$ pelaku usaha sektor informal memperoleh sumber bahan baku dari sektor lain, seperti pasar, toko, industri lain, atau bahkan impor. Selanjutnya, $58,3 \%$ pelaku usaha sektor informal yang telah mengalami proses formalisasi memiliki latar belakang pendidikan tinggi (SMA ke atas). Situasi ini kontras dengan anggapan yang mengidentikkan pelaku sektor informal berlatar belakang pendidikan rendah atau bahkan tidak sekolah. Hal ini dipengaruhi oleh asumsi bahwa sektor informal tidak memerlukan keterampilan khusus. Semua pekerja dengan berbagai latar belakang pendidikan dan keterampilan dapat masuk pada sektor pekerjaan informal. Jika dihubungkan dengan kemampuan menentukan target pemasaran, Prasetyo dan Harjanti (2013) mengemukakan bahwa tingkat pendidikan merupakan salah satu faktor penyebab meningkatkanya kemampuan menentukan target pemasaran pada pelaku usaha informal. Hal ini relevan dengan ka- 


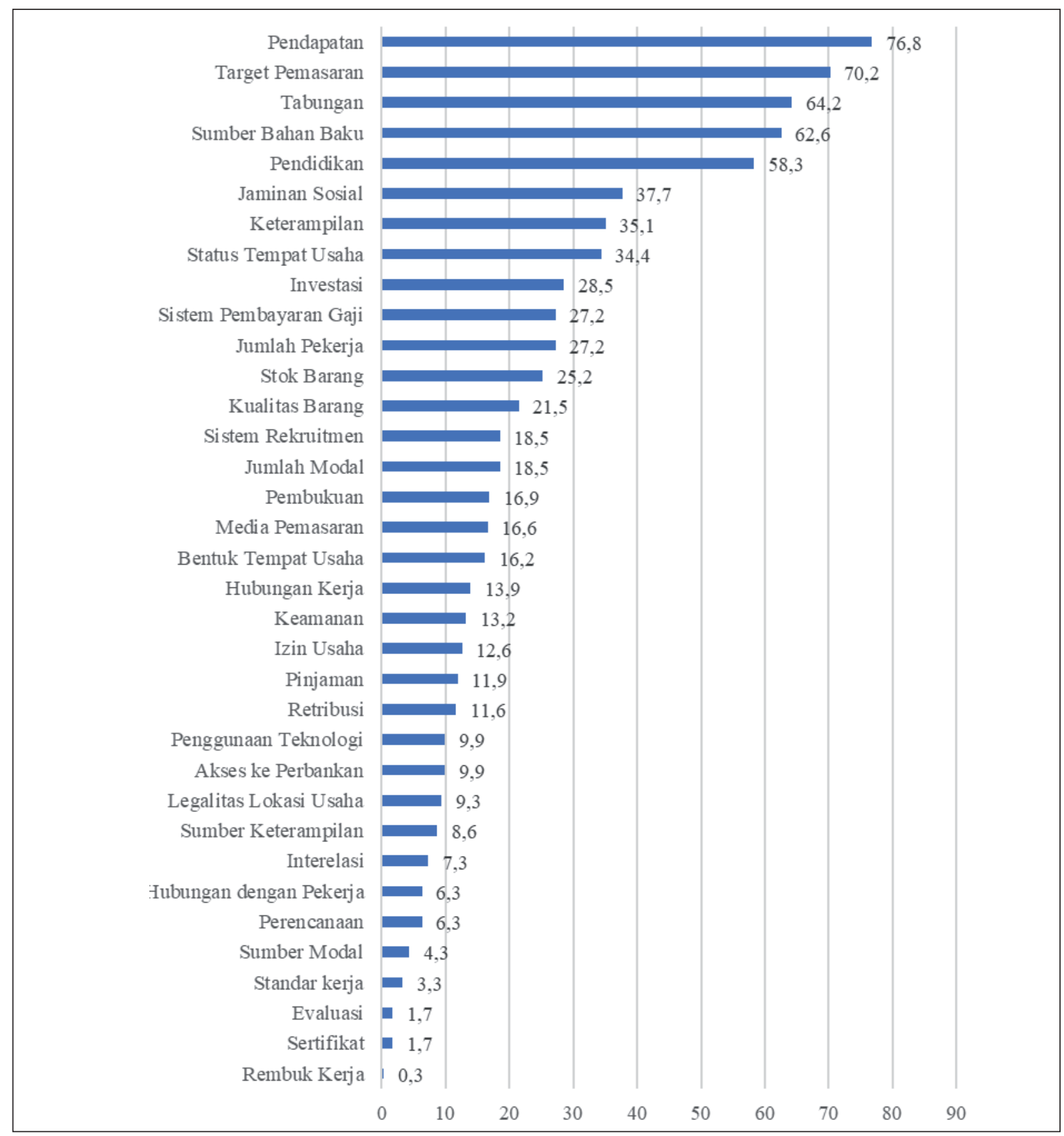

Gambar 5. Persentase karakteristik sektor informal yang telah mengalami proses formalisasi

sus di Kota Palembang yang menunjukkan bahwa sebagian besar pelaku usaha informal memiliki pendidikan tinggi, maka tidak mengherankan jika banyak pelaku usaha informal yang memiliki kemampuan menentukan target pemasaran.

Peningkatan partisipasi pelaku usaha sektor informal terhadap jaminan sosial merupakan salah satu wujud penyetaraan hak-hak pekerja di tengah masyarakat rentan. Berdasarkan karakteristik jaminan sosial, $37,7 \%$ pelaku usaha sektor informal terdaftar dan aktif membayar jaminan sosial yang diselengarakan oleh pemerintah, seperti BPJS Kesehatan dan BPJS Ketenagakerjaan. Menurut ILO (2020), pekerja informal memiliki akses yang rendah terhadap jaminan sosial sehingga partisipasi masyarakat rentan terhadap jaminan sosial harus selalu ditingkatkan, seperti jaminan sosial yang berkaitan dengan kesehatan dan keselamatan kerja (Safaria dkk., 2003). Dilihat dari tingkat keterampilan, 35,2\% pelaku usaha sektor informal di Kota Palembang memiliki tingkat keterampilan tinggi (tidak semua orang dapat melakukannya), seperti menjahit, reparasi motor/mobil, pedagang kuliner, pangkas rambut, komputer. Jika berdasarkan status tempat 
usaha, pelaku usaha sektor informal umumnya menjalankan usahanya dengan sistem berpindah tempat. Hal ini mengakibatkan I status tempat usahanya sektor informal tergolong bebas, menumpang atau berpindah. Kajian ini menemukan bahwa $34,4 \%$ pelaku usaha sektor informal memiliki status tempat usaha sewa atau pribadi (terpisah antara modal/aset pribadi dan modal/ aset usaha).

Berdasarkan kemampuan investasi, 28,5\% pelaku usaha sektor informal memiliki investasi atas nama pribadi berupa tanah, rumah, tempat usaha, dan lain sebagainya. Dilihat dari sistem pembayaran gaji, pelaku usaha sektor informal yang telah memiliki karyawan menggunakan sistem pembayaran gaji secara teratur sebesar $27,2 \%$. Dengan demikian, pelaku usaha sektor informal tersebut telah mengalami proses formalisasi sebab biasanya pelaku usaha sektor informal menggunakan sistem pembayaran gaji yang tidak teratur atau tidak tetap. Selanjutnya, 27,2\% pelaku usaha sektor informal memiliki pekerja yang dibayar. Studi ini menemukan bahwa pelaku usaha sektor informal paling sedikit memiliki satu orang pekerja dan maksimal 8 orang pekerja dibayar. Selanjutnya, $25,2 \%$ pelaku usaha sektor informal di Kota Palembang telah mengalami proses formalisasi berdasarkan kemampuan stok barang minimal hingga untuk 1 atau 2 minggu ke depan. Selan itu, $21,5 \%$ pelaku usaha sektor informal memiliki kualitas barang/jasa standar atau tinggi. Hal ini dibuktikan dari adanya beberapa penghargaan yang didapatkan oleh pelaku usaha sektor informal pada saat mengikuti beberapa kegiatan yang diadakan oleh pihak pemerintah/ swasta.

Meskipun hubungan kerja antara pemiliki usaha informal dan pekerja biasanya berupa hubungan kekeluargaan atau kepercayaan, terdapat $18,5 \%$ pelaku usaha sektor informal yang menerapkan sistem rekruitmen dengan standar sektor formal, seperti melakukan tes tertulis atau wawancara. Dilihat dari jumlah modal usaha yang digunakan, $18,5 \%$ sektor informal di Kota Palembang telah mengalami proses formalisasi sebab menggunakan jumlah modal usaha lebih besar dari sepuluh juta rupiah. Secara umum, rentang jumlah modal usaha pelaku usaha sektor informal berkisar dari Rp. 50.000 hingga 45 juta rupiah. Rata-rata jumlah modal usaha yang digunakan oleh pelaku usaha sektor informal di Kota Palembang sebesar tujuh juta rupiah. Ditinjau dari sisi administrasi pembukuan, $16,9 \%$ pelaku usaha sektor informal telah mengalami proses formalisasi sebab mereka telah memiliki administrasi pembukuan yang baik. Dari penggunaan media pemasaran, $16,6 \%$ pelaku usaha sektor informal di Kota Palembang telah mengalami proses formalisasi, sebab menggunakan media pemasaran modern, seperti marketplace, website atau media sosial. Kemajuan teknologi mampu memberikan dampak yang cukup baik pada pelaku usaha sektor informal sebab pelaku usaha sektor informal dapat melakukan pemasaran barang/jasa melalui media online. Dampaknya, area pemasaran menjadi lebih luas dan memperbesar peluang peningkatan pendapatan.

Berdasarkan bentuk tempat usaha, 16,2\% pelaku usaha sektor informal telah mengalami proses formalisasi sebab memiliki bentuk tempat usaha permanen. Pelaku usaha sektor informal identik dengan bentuk tempat usaha nonpermanen atau semi permanen. Hal ini disebabkan usaha yang dijalankan tidak terdaftar sehingga untuk memudahkan pergerakan, pelaku usaha sektor informal memilih menggunakan bentuk tempat usaha nonpermanen atau semi permanen. Dengan maksud, jika suatu saat ada penertiban atau penggusuran, pelaku usaha sektor informal tinggal membongkar tempat usahanya dan memindahkan ke tempat lain. Temuan ini relevan dengan Sarjono (2004) yang menyatakan bahwa salah satu ciri formalisasi adalah perubahan tempat usaha dari nonpermanen (pinggir jalan) ke tempat permanen (kios atau toko swalayan). Perubahan karakteristik yang ditemukan pada pelaku usaha sektor informal di Kota Palembang menunjukkan bahwa sektor informal bukan lagi sebuah entitas monolitis yang didominasi oleh pekerja miskin dan kegiatan produktivitas rendah (Nazara, 2010). Hal ini disebabkan terdapat potensi yang dinilai mampu membuat usaha informal bertransisi menjadi sektor formal. Pada konteks penelitian ini, potensi tersebut terlihat dari tingkat pendapatan, pendidikan, tabungan, target pemasaran, sumber bahan baku, dan partisipasi pada jaminan sosial (karakteristik yang telah mengalami proses formalisasi). 
Tabel 3. Hasil analisis Chi-Square karakteristik sektor informal dan tahapan formalisasi

\begin{tabular}{clcclc} 
No. & \multicolumn{1}{c}{ Karakteristik } & $\begin{array}{c}\text { Pearson } \\
\text { Chi-Square }\end{array}$ & No. & Karakteristik & $\begin{array}{c}\text { Pearson } \\
\text { Chi-Square }\end{array}$ \\
\hline 1 & Izin Usaha & 0,000 & 19 & Bentuk Tempat Usaha & 0,000 \\
\hline 2 & Sertifikat & 0,000 & 20 & Status Tempa Usaha & 0,000 \\
\hline 3 & Standar Kerja & 0,000 & 21 & Perencanaan & 0,000 \\
\hline 4 & Retribusi & 0,000 & 22 & Rembuk Kerja & 0,000 \\
\hline 5 & Legalitas Lokasi Usaha & 0,014 & 23 & Pembukuan & 0,000 \\
\hline 6 & Keamanan & 0,000 & 24 & Stok barang & 0,000 \\
\hline 7 & Pendidikan & 0,208 & 25 & Kualitas Barang & 0,000 \\
\hline 8 & Keterampilan & 0,000 & 26 & Interelasi & 0,000 \\
\hline 9 & Sumber Keterampilan & 0,000 & 27 & Penggunaan Teknologi & 0,000 \\
\hline 10 & Jaminan Sosial & 0,539 & 28 & Media Pemasaran & 0,000 \\
\hline 11 & Akses ke Perbankan & 0,000 & 29 & Target Pemasaran & 0,025 \\
\hline 12 & Jumlah Modal & 0,000 & 30 & Evaluasi & 0,000 \\
\hline 13 & Sumber Modal & 0,318 & 31 & Jumlah Pekerja & 0,000 \\
\hline 14 & Pinjaman Modal & 0,388 & 32 & Sistem Rekruitmen & 0,000 \\
\hline 15 & Sumber Bahan Baku & 0,001 & 33 & Hubungan Kerja & 0,000 \\
\hline 16 & Pendapatan & 0,000 & 34 & Hubungan dengan Pekerja & 0,000 \\
\hline 17 & Tabungan & 35 & Sistem Pembayaran Gaji & 0,000 \\
\hline 18 & Investasi & 0,000 & & & \\
\hline
\end{tabular}

Hasil analisis Chi-Square menunjukkan terdapat empat karakteristik yang memiliki nilai Pearson Chi-Square $>0,05$, yaitu pendidikan, jaminan sosial, sumber modal, dan pinjaman modal (Tabel 3). Dengan kata lain, karakteristik pendidikan, jaminan sosial, sumber modal, dan pinjaman modal tidak memiliki hubungan signifikan dengan proses formalisasi sektor informal di Kota Palembang. Sementara itu, karakteristik lain ( izin usaha, standar kerja, retribusi, legalitas lokasi usaha, keamanan, keterampilan, sumber keterampilan, akses ke perbankan, jumlah modal, sumber bahan baku, pendapatan, tabungan, investasi, bentuk tempat usaha, status tempat usaha, perencanaan, rembuk kerja, pembukuan, stok barang, kualitas barang, interelasi (kerjasama dengan sektor lain), penggunaan teknologi, media pemasaran, target pemasaran, evaluasi, jumlah pekerja, sistem rekruitmen, hubungan kerja, hubungan dengan pekerja, dan sistem pembayaran gaji memiliki hubungan signifikan dengan proses formalisasi sektor informal di Kota Palembang.

\section{FAKTOR YANG MEMENGARUHI PROSES FORMALISASI SEKTOR INFORMAL}

Hasil penelitian ini menunjukkan bahwa sebagian besar proses formalisasi sektor informal terjadi secara alami. Hal ini ditunjukkan oleh mayoritas pelaku usaha sektor informal yang menjawab peningkatan usaha yang mereka lakukan atas inisiatif personal $(98,3 \%)$. Salah satu pelaku usaha sektor informal yang bekerja sebagai pedagang nasi goreng dan sate mengungkapkan bahwa:

...setiap orang yang bekerja pasti memiliki niat untuk meningkatkan usaha, termasuk saya. Kalau pekerjaan lebih besar, harapannya pendapatan juga bertambah...

Pendapat yang serupa juga diungkapkan informan yang bekerja sebagai tukang jahit:

...ingin usaha yang saya jalankan bisa lebih besar, supaya menambah pendapatan...

Dua pelaku usaha ini mengungkapkan bahwa mereka memiliki inisiatif untuk membuat usaha mereka menjadi lebih baik. Keinginan tersebut muncul sebagai keputusan sadar untuk berubah atau meningkatkan usahanya ke jenjang yang lebih baik. Pada dasarnya pelaku usaha sektor informal di Kota Palembang tidak memahami perubahan karakteristik usaha yang mereka alami sebagai proses formalisasi. Peningkatan usaha biasanya dilakukan sesuai keinginan dengan mempertimbangkan banyak faktor, seperti skala 
usaha, jumlah pendapatan, tabungan, jumlah pelangan, dan lain sebagainya, sebagaimana diungkapkan dalam kutipan wawancara berikut ini: kan usaha...

...butuh modal besar untuk meningkat-

...sepi pelanggan, jadi pendapatan untuk makan pun kurang, kalaupun ramai satu hari dapat 80 ribu sampai 100 ribu...

Berdasarkan informasi tersebut, pendapatan yang diperoleh sangat tergantung dari jumlah konsumen yang datang. Semakin banyak banyak konsumen, semakin tinggi pendapatan yang diperoleh. Pendapatan tersebut dikumpulkan, lalu dijadikan modal untuk mengembangkan usaha. Masalahnya, tidak ada yang dapat menjamin pelaku usaha sektor informal mendapatkan konsumen yang banyak. Oleh karena itu, jumlah konsumen atau pelanggan sangat menentukan keinginan pelaku usaha sektor informal di Kota Palembang untuk melakukan formalisasi.

Sebagian besar responden mengemukakan belum adanya intervensi pemerintah terhadap usaha yang dijalankan. Temuan ini relevan dengan Aparcana (2017) yang menyatakan bahwa peran intervensi pemerintah dalam proses formalisasi sangat diperlukan, sebab kebijakan yang 'ramah informal' akan memudahkan tercapainya proses formalisasi ${ }^{1}$. Rendahnya intervensi pemerintah menyebabkan proses formalisasi tidak terjadi secara sistematis, tetapi justru terjadi secara 'acak' atau 'naik-turun'. Pola ini dipengaruhi oleh faktor pendorong proses formalisasi yang sebagian besar berasal dari inisiatif personal. Inisiatif personal memberikan dampak 'acuh' atau 'tanpa beban'. Maknanya, tidak ada paksaan

\footnotetext{
Aparcana (2017) mengambil contoh pendekatan formalisasi pada pengelola limbah informal di beberapa negara berpenghasilan rendah dan menengah. Hasil kajian ini menunjukkan agenda formalisasi sektor informal tidak tergantung pada pendekatan yang digunakan, melainkan pada kemampuan mengelola hambatan formalisasi yang sebagian besar disebabkan oleh aspek hukum/kebijakan $(75 \%)$, organisasi (50\%), keuangan (45\%), sosial (40\%), dan teknis $(35 \%)$. Formalisasi juga dipengaruhi oleh faktor inklusi pada tiap negara. Negara yang memiliki perspektif positif atau ramah terhadap sektor informal dipercaya lebih mudah melakukan proses formalisasi sektor informal dibanding negara yang anti informalitas.
}

atau dorongan kuat untuk pelaku usaha sektor informal secara konsisten meningkatkan usahanya. Informasi ini diperoleh dari salah satu responden yang mengungkapkan:

\section{...kapan pun boleh, jika memungkinkan} dan diminta oleh pemerintah...

Tampak dari jawabannya informan tersebut menunggu anjuran dari pemerintah untuk melakukan registrasi usaha. Apabila belum ada intruksi dari pemerintah, mereka akan tetap menjalankan usahanya secara informal. Hal ini juga disebabkan oleh keterbatasan pengetahuan pada pelaku usaha, seperti yang diungkapkan berikut ini:

...tidak mengerti bagaimana cara mendaftarkan usaha, apa syarat dan kegunaannya. Jika ada informasi, kemungkinan saya mau daftar usaha...

Berdasarkan jawaban informan tersebut, keterbatasan informasi menjadi salah satu penyebab rendahnya keinginan pelaku usaha informal melakukan pendaftaran usaha meskipun mereka telah memiliki sebagian karakteristik usaha formal. Kondisi inilah yang menciptakan proses formalisasi yang 'acak'. Pelaku usaha sektor informal yang telah mengalami proses formalisasi secara dimensi ekonomi, sosial, manajemen, dan ketenagakerjaan, belum tentu mau melakukan proses formalisasi secara hukum. Dengan demikian, pelaku usaha sektor informal yang telah berada di tahap formal bisa kapan saja kembali ke tahap transisi atau bahkan ke tahap informal. Namun, tidak menutup kemungkinan pelaku usaha sektor informal juga dapat langsung berada di tahap formal. Dengan kata lain, proses formalisasi tanpa adanya intervensi dapat menyebabkan rendahnya rasa tanggung jawab dan keinginan pelaku usaha sektor informal untuk secara konsisten meningkatkan usahanya. Hal ini dikarenakan intervensi pemerintah (pemberdayaan masyarakat) dapat meningkatkan kapasitas pekerja dan mendorong berlangsungnya keberlanjutan pekerjaan yang dilakukan (Vibriyanti, 2014).

Keberlanjutan proses formalisasi sektor informal diharapkan menunjukkan perkembangan positif ketika pelaku usaha sektor informal secara 


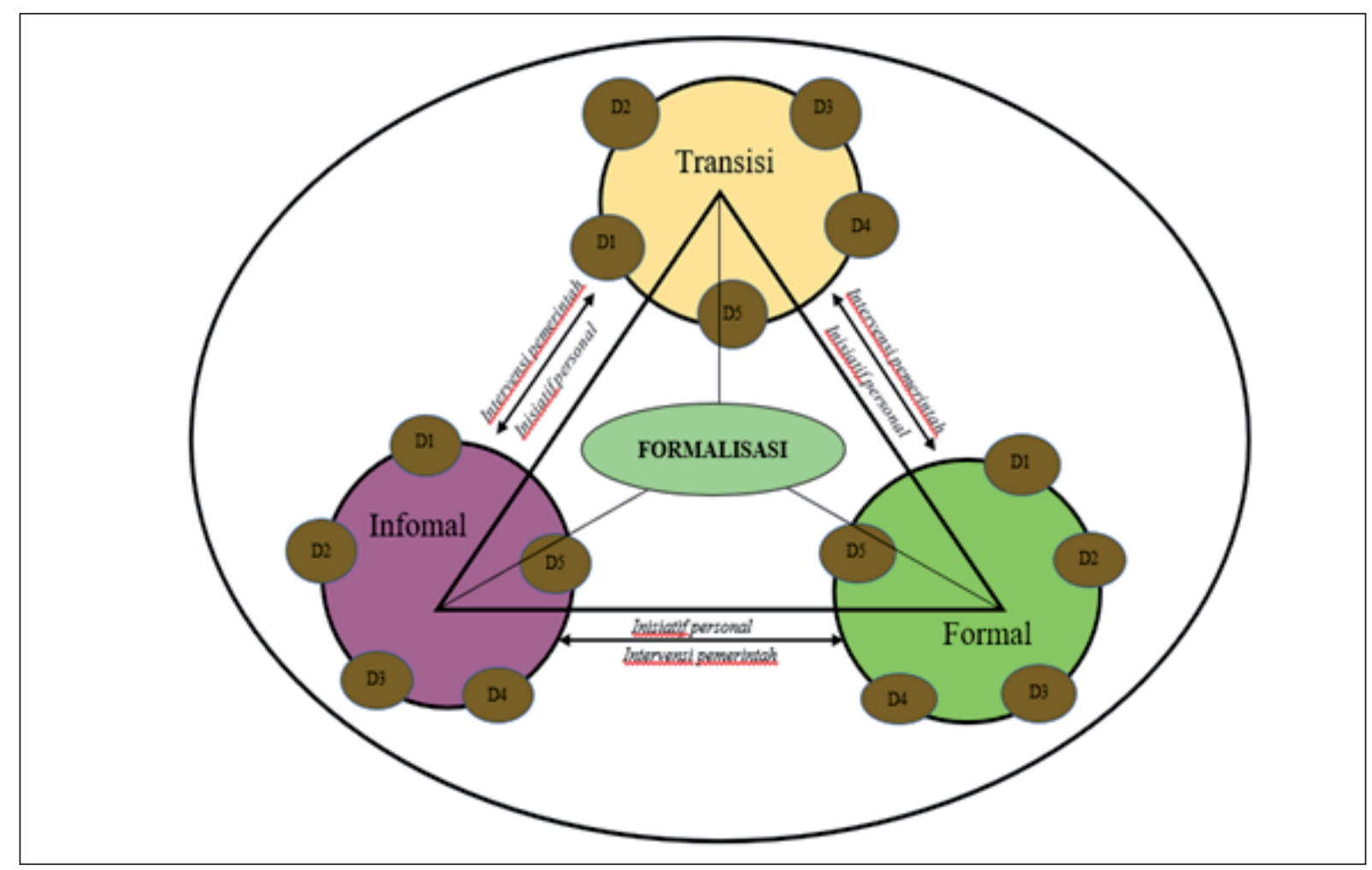

Gambar 6. Model formalisasi sektor informal di Kota Palembang

sukarela mendaftarkan usahanya secara resmi. Harapan tersebut dapat tercapai jika pelaku usaha sektor informal yang telah masuk ke dalam tahap transisi didampingi secara optimal melalui program pemberdayaan sektor informal. Pelaku usaha sektor informal yang berada pada tahap transisi dapat dianggap sebagai 'sektor informal potensial' sebab berdasarkan karakteristiknya telah mengalami transisi seperti sektor formal. Meskipun masih sebagian, namun upaya pemberdayaan atau dalam hal ini intervensi pemerintah sangat diharapkan untuk dapat masuk dan mendampingi para pelaku usaha sektor informal potensial.

Dilihat dari tingkat pendapatan, pendidikan, dan kemampuan menabung sebagian besar pelaku usaha sektor informal di Kota Palembang tergolong baik, karena telah mengalami proses formalisasi. Oleh karena itu, pelaku usaha sektor informal di Kota Palembang hanya perlu difasilitasi agar dapat berbagi informasi dan pengetahuan terkait mekanisme pendapaftaran usaha, serta keuntungan dan kerugian pendaftaran usaha. Secara ringkas, kajian ini merumuskan proses formalisasi sektor informal di Kota Palembang dalam kerangka model pada Gambar 6.

\section{DAMPAK FORMALISASI PADA PELAKU USAHA SEKTOR INFORMAL DI KOTA PALEMBANG}

Proses formalisasi sektor informal berdampak positif terhadap pelaku usaha di Kota Palembang. Pelaku usaha sektor informal yang telah memperoleh izin usaha merasa lebih aman dalam menjalankan usaha. Mereka juga dapat lebih tenang dalam menjalankan usaha tanpa harus merasa takut tergusur. Peluang mendapatkan pendapatan yang lebih tinggi juga terjadi karena waktu kerja yang lebih teratur. Pelaku usaha sektor informal juga berkesempatan untuk mengikuti berbagai pelatihan dan mendapatkan bantuan modal dari pemerintah atau pihak swasta. Peningkatan partisipasi pelaku usaha sektor informal dalam berbagai pelatihan diharapkan dapat meningkatkan produktivitas dan daya saing kegiatan usaha tersebut. Hal ini dikarenakan semakin tinggi daya saing pekerja maka semakin tinggi pula daya saing ekonominya (Adam, 2016).

Temuan ini juga relevan dengan Funkhouser (1997) yang menyatakan bahwa intervensi pemerintah untuk mengupayakan perbaikan pada sektor informal dapat memberikan peluang pendapatan yang lebih baik pada pekerjanya. Bukan 
hanya itu, pelaku usaha sektor informal memiliki waktu yang lebih lama dalam menjalankan usahanya akibat adanya relokasi dari pemerintah (Wildaniyati \& Muhammad, 2016). Untuk masalah keamanan, pekerja dengan status usaha formal memiliki keamanan kerja disebabkan terhindar dari tindakan penggusuran atau punggutan liar di lokasi (Roever, 2016).

Akses ke perbankan untuk melakukan pinjaman modal usaha menjadi lebih mudah jika telah memiliki izin usaha. Dinas Koperasi dan UMKM Kota Palembang juga memiliki program pembinaan, pelatihan dan pendampingan pada pelaku usaha kecil yang telah memiliki izin usaha. Dinas Koperasi dan UMKM memiliki bantuan modal sebesar tiga juta rupiah untuk setiap pelaku usaha terdaftar yang terpilih. Dengan adanya proses formalisasi sektor informal, pelaku usaha sektor informal diharapkan dapat mengakses segala bentuk pelayanan peningkatan usaha yang ada di Kota Palembang.

\section{KESIMPULAN}

Pelaku usaha sektor informal di Kota Palembang telah mengalami proses formalisasi. Berdasarkan prosesnya, formalisasi sektor informal di Kota Palembang dibedakan menjadi parsial dan general. Secara parsial, sebagian besar pelaku usaha sektor informal di Kota Palembang berada pada tahap transisi. Pada dimensi ekonomi, proporsi pelaku usaha sektor informal yang berada pada tahap formal lebih besar dari informal. Sementara itu, secara general, pelaku usaha sektor informal sebagian besar berada pada tahap informal, diikuti transisi dan formal. Meskipun jumlah dan persentase pelaku usaha informal yang berada pada tahap transisi dan formal relatif kecil, tetapi data dan informasi dalam penelitian ini menunjukkan bukti bahwa proses formalisasi telah terjadi pada pelaku usaha sektor informal di Kota Palembang. Hal ini terlihat dari perubahan karakteristik pelaku usaha dari informal-formal. Misalnya, dari tidak memiliki izin usaha menjadi berizin usaha, dari berpendapatan di bawah upah minimum menjadi sama atau di atas upah minimum.

Proses formalisasi sektor informal di Kota Palembang umumnya dipengaruhi inisiatif per- sonal pelaku usaha. Dapat dikatakan, formalisasi di Kota Palembang terjadi secara alami. Hal ini menyebabkan pola formalisasi sektor informal yang terbentuk di Kota Palembang, bersifat 'acak' atau 'naik turun'. Pelaku usaha sektor informal yang telah mengalami proses formalisasi pada dimensi sosial, ekonomi, manajemen, dan ketenagakerjaan, belum tentu melakukan proses formalisasi secara hukum. Hal ini dapat disebabkan oleh faktor ketidaksiapan ataupun kurangnya pemahaman terkait dampak yang ditimbulkan ketika usaha menjadi formal.

Beberapa dampak formalisasi yang dapat dirasakan oleh pelaku usaha sektor informal di Kota Palembang antara lain; keamanan usaha, peluang pendapatan, pelatihan, dan bantuan modal. Sebagai rekomendasi, perlu adanya gradasi konsep kegiatan ekonomi, bukan hanya sektor informal dan formal, melainkan sektor informal, transisi, dan formal. Sektor transisi dapat dibagi lagi menjadi tiga, yaitu transisi awal, tengah, dan akhir. Pada akhirnya, sektor informal yang termasuk dalam kelompok transisi dapat disebut sebagai 'sektor informal potensial'. Pengklasifikasian ini dapat membantu pembuat kebijakan dalam memetakan sektor informal potensial yang kemudian dapat dijadikan objek untuk kegiatan pemberdayaan sektor informal sehingga potensi sektor informal untuk berkembang dan meningkatkan usaha lebih mudah tercapai. Penelitian ini memiliki keterbatasan sebab kurang melibatkan pelaku usaha formal. Oleh karena itu, kajian terkait karakteristik pendukung dan penghambat formalisasi dan cara pengelolaan hambatan hingga menjadi usaha formal belum dilakukan secara komprehensif. Kajian selanjutnya diharapkan dapat melibatkan sampel penelitian dari pelaku usaha formal yang awalnya informal.

\section{DAFTAR PUSTAKA}

Adam, L. (2016). Membangun daya saing tenaga kerja Indonesia melalui peningkatan produktivitas. Jurnal Kependudukan Indonesia, 11(2), 71-84. https://doi.org/10.14203/jki.v11i2.205

Aparcana, S. (2017). Approaches to formalization of the informal waste sector into municipal solid waste management systems in low- and middleincome countries: Review of barriers and success factors. Waste Management, 61, 593-607. https://doi.org/10.1016/j.wasman.2016.12.028 
Armansyah, \& Aryaningrum, K. (2017). Analisis karakteristik demografi pekerja wanita sektor informal pada era Masyarakat Ekonomi ASEAN di Kota Palembang. Populasi, 25(1), 52-63. https://jurnal.ugm.ac.id/populasi/article/ view/32415/19530

Armansyah, \& Taufik, M. (2018). Representasi perempuan pekerja migran menurut laki-laki di Kota Palembang. Populasi, 26(1), 26-38. https://jurnal.ugm.ac.id/populasi/article/ view/38687/22064

Armansyah, Sukamdi, \& Pitoyo, A. J. (2019). Informal sector - A survival or consolidation livelihood strategy: A case study of the informal sector entrepreneurs in Palembang City, Indonesia. RJOAS, 11(95), 104-110. https://rjoas.com/ issue-2019-11/article_13.pdf

BPJS Ketenagakerjaan maksimalkan pekerja di sektor informal. (2017, 14 Maret). Radar-Palembang. com. http://www.radar-palembang.com/ bpjs-ketenagakerjaan-maksimalkan-pesertadi-sektor-informal/

BPS [Badan Pusat Statistik]. (2017). Kota Palembang dalam angka 2017. Badan Pusat Statistik Kota Palembang.

(2018). Kota Palembang dalam angka 2018. https://palembangkota.bps.go.id/publication/2018/08/16/ b3fad0b55076a742da4af61b/kota-palembangdalam-angka-2018.html

Brata, A. G. (2010). Vulnerability of urban informal sectors: Street vendors in Yogyakarta, Indonesia. Theoretical and Empirical Researches in Urban Management, 5(5), 47-58. https://www. jstor.org/stable/24861505

Canclini, N. G. (2018). A culture of informality. Urban Studies, 56(3), 488-493. https://doi. org/10.1177/0042098018782635

Chen, M. A., \& Vanek, J. (2013). Informal employment revisited: Theories, data \& policies. Indian Journal of Industrial Relations, 48(3), 390-401. https://www.jstor.org/stable/23510786

Chirisa, I. (2014). The role of the informal sector in African regional integration: Scope and limits. Insight on Africa, 6(2), 131-144. https://doi. org/10.1177/0975087814535425

Creswell, J. W. (2016). Research design: Pendekatan metode kualitatif, kuantitatif, dan campuran. Pustaka Pelajar.

Funkhouser, E. (1997). Mobility and labor market segmentation: The urban labor market in El Salvador. Economic Development and Cultural Change, 46(1), 123-153. https://doi. org/10.1086/452324
Gibson, B., \& Flaherty, D. (2016). Juridical and functional informality: From theory to practical policy. Margin: The Journal of Applied Economic Research, 10, 409-445. https://doi. org/10.1177/0973801016659729

ILO. (2016, 15 Januari). R204 - Transition from the informal to the formal economy recommendation, 2015 (No. 204). http://www.ilo. org/employment/units/emp-invest/informaleconomy/WCMS_443501/lang--en/index.htm

ILO. (2019). Formalization in Chile. http://www. ilo.org/empent/Publications/WCMS_725018/ lang--en/index.htm

ILO. (2020). Covid-19 crisis and the informal economy: Immediate responses and policy challenges. http://www.ilo.org/global/topics/ employment-promotion/informal-economy/ publications/WCMS_743623/lang--en/index. htm

Mahmuddin. (2015). Formalisme agama dalam perspektif gerakan sosial: Prospek dan tantangan di masa depan. Jurnal Diskursus Islam, 3(1), 37-48. https://doi.org/10.24252/jdi.v3i1.194

Nazara, S. (2010). Ekonomi informal di Indonesia: Ukuran, komposisi, dan evolusi. Organisasi Perburuhan Internasional. https://www. ilo.org/wcmsp5/groups/public/---asia/---robangkok/---ilo-jakarta/documents/publication/ wcms_145402.pdf

Olmedo, C., \& Murray, M. J. (2002). The formalization of informal/precarious labor in contemporary Argentina. International Sociology, 17(3), 421-443. https://doi. org/10.1177/0268580902017003004

Pekerja sektor informal di Sumsel diasuransikan. (2012, 19 September). AntaraSumsel. https:// sumsel.antaranews.com/berita/266482/pekerjasektor-informal-di-sumsel-diasuransikan

Pitoyo, A. J. (1999). Pedagang kaki lima pada masa krisis. Populasi, 10(2), 73-97. https://jurnal. ugm.ac.id/populasi/article/view/12485/9037

Prasetyo, T., \& Harjanti, D. (2013). Modal sosial pengusaha mikro dan kecil sektor informal dan hubungannya dengan kinerja bisnis di wilayah Jawa Timur. Agora, 1(3). https://media.neliti. com/media/publications/36260-ID-modalsosial-pengusaha-mikro-dan-kecil-sektorinformal-dan-hubungannya-dengan-ki.pdf

Rahmatunnair. (2012). Paradigma formalisasi hukum Islam di Indonesia. Ahkam, 12(1), 99-108. https://doi.org/10.15408/ajis.v12i1.984

Ramdan, I. M. (2012). Memperbaiki kondisi kesehatan dan keselamatan kerja sektor informal melalui program Corporate Social Responsibility 
perusahaan. Jurnal Manajemen Pelayanan Kesehatan, 15(1), 2-6. https://journal.ugm. ac.id/jmpk/article/viewFile/2505/2241

Roever, S. (2016). Informal trade meets informal governance: Street vendors and legal reform in India, South Africa, and Peru. Cityscape: A Journal of Policy Development and Research, 18(1), 27-46. http://www.jstor.org/ stable/26328239

Safaria, A. F., Suhanda, D., \& Riawanti, S. (2003). Hubungan perburuhan di sektor informal: Permasalahan dan prospek. https://media.neliti. com/media/publications/472-ID-hubunganperburuhan-di-sektor-informal-permasalahandan-prospek.pdf

Sarjono, Y. (2004). Interelasi antara sektor ekonomi formal dan sektor ekonomi informal (Studi tentang formalisasi pedagang kakilima di Surakarta dalam perspektiffenomenologi [Disertasi doktoral, Universitas Airlangga]. Universitas Airlangga Repository. http://repository.unair. ac.id/32574/

Smart, A., \& Smart, J. (2017). Formalization as confinement in colonial Hong Kong. International Sociology, 32(4), 437-453. https://doi. org/10.1177/0268580917701603

Soebyakto, B. B., \& Armansyah. (2016). Migrant women working at informal sectors: Empirical study in Kuto Batu Village, Ilir Timur II Palembang City. International Journal of Humanities and Social Science, 6(4), 125-137. https://repository.unsri.ac.id/14502/1/ migrant_women_working_at_informal_sectors-_empirical_study_in_kuto_batu_16.pdf

Sugiyono. (2016). Metode penelitian kombinasi (Mixed methods). Alfabeta.
Taufik, M., Monanisa, Nengyanti, Soebyakto, B. B., \& Armansyah. (2019). Kontribusi perempuan pekerja dalam keluarga di perkotaan. Eco-Build Journal, 3(2), 30-39. http://jurnal.umberau. ac.id/index.php/ecobuild/article/view/395/246

Vibriyanti, D. (2014). Kondisi sosial ekonomi dan pemberdayaan nelayan tangkap Kota Tegal, Jawa Tengah. Jurnal Kependudukan Indonesia, 9(1). https://doi.org/10.14203/jki.v9i1.10

Walikota Palembang janji bebaskan biaya IMB dan sertifikat. (2012, 25 Juli). kompas. com. https://properti.kompas.com/ $\mathrm{read} / 2012 / 07 / 25 / 15364956 /$ walikota.palembang.janji.bebaskan.biaya.imb.dan.sertifikat

Wauran, P. C. (2012). Strategi pemberdayaan sektor informal perkotaan di Kota Manado. Jurnal Pembangunan Ekonomi dan Keuangan Daerah (PEKD), 7(3), 1-30. https://media.neliti. com/media/publications/45004-ID-strategipemberdayaan-sektor-informal-perkotaan-dikota-manado.pdf

Wildaniyati, A., \& Muhammad, S. (2016). Implikasi kebijakan relokasi pedagang kaki lima terhadap usaha pedagang Pasar Malang Night Market (Studi Kasus di Pasar Malang Night Market Kota Malang). Jurnal Ekomaksi, 5(1), 35-45. http://www.unmermadiun.ac.id/ejurnal/index. php/ekomaks/article/view/145

Wulantari, R. A., \& Armansyah. (2018). Analisis dampak karakteristik demografi pada perolehan pendapatan pekerja perempuan sektor informal di Kota Palembang. The Journal of Society \& Media, 2(1), 37-52. https://journal.unesa.ac.id/ index.php/jsm/article/view/2328/pdf_1 